Shanghai Rising in a Globalizing World

\author{
Shabid Yusuf \\ Weiping Wu
}

If the Chinese economy can sustain its growth rate, it will rival the United States in a

few decades. And if Shanghai can sustain its preeminence in China, it is the East Asian city most likely to become a global center on a par with New York, London, and Tokyo - if China can become open and competitive and if Shanghai can greatly improve in terms of industry, housing, infrastructure, and quality of Iffe, among other things.
The World Bank

Development Research Group June 2001 
Policy Research Working Paper 2617

\section{Summary findings}

In a globalizing world, cities at or near the apex of the international urban hierarchy are among the favored few-New York, London, and Tokyo-that have acquired large economic, cultural, and symbolic roles. Among a handful of regions that aspire to such a rolesuch as Hong Kong, Miami, and São Paulo-Shanghai has reasonable long-term prospects.

If the Chinese economy can sustain its growth rate, it will rival the United States in a few decades. And if Shanghai can sustain its preeminence in China, it is the East Asian city most likely to become a global center.

Yusuf and $\mathrm{W} u$ explore the makings of a world city, identify ingredients essential for that status, indicate national and municipal policies that may set Shanghai on the path to being a global city, and show how such policies are being implemented.

As urbanization continues, the authors say, and as information technology and finance related service activities take on even more importance, the number of regional and global centers could increase, but only if they satisfy some exacting requirements. Shanghai's chances, for example, depend on the extent to which China opens up and on a host of municipal policiespolicies that emphasize Shanghai's industrial strength, substantially enlarge its base of information technology and producer services, ensure an adequate supply of skills, expand available housing and infrastructure enough to meet demand, and improve the quality of life.

This paper is a product of the Development Research Group. Copies of the paper are available free from the World Bank, 1818 H Street NW, Washington, DC 20433. Please contact Shahid Yusuf, room MC3-511, telephone 202-458-2339, fax 202-522-1150, email address syusuf@worldbank.org. Policy Research Working Papers are also posted on the Web at http://econ.worldbank.org. June 2001. (40 pages)

The Policy Research Working Paper Series disseminates the findings of work in progress to encourage the exchange of ideas about development issues. An objective of the series is to get the findings out quickly, even if the presentations are less than fully polished. The papers carry the names of the authors and should be cited accordingly. The findings, interpretations, and conclusions expressed in this paper are entirely those of the authors. They do not necessarily represent the view of the World Bank, its Executive Directors, or the countries they represent. 


\title{
Shanghai Rising in a Globalizing World
}

\author{
June 2001
}

\author{
Shahid Yusuf \\ Development Economics \\ The World Bank \\ 1818 H Street NW \\ Washington, DC 20433 \\ Tel: $202-458-2339$ \\ Fax: 202-522-0056 \\ Email: syusuf@worldbank.org
}

\author{
Weiping $\mathrm{Wu}$ \\ Department of Urban Studies and Planning \\ Virginia Commonwealth University \\ 812 West Franklin Street \\ Richmond, VA 23284-2008, USA \\ Tel: 01 (804) 828-2489 \\ Fax: 01 (804) 828-6681 \\ email: wwu@vcu.edu
}





\section{Shanghai Rising in a Globalizing World*}

When one thinks of world cities, a handful of names comes immediately to mind: New York, London, and possibly Tokyo (Friedmann 1998). ${ }^{1}$ They are classified as world cities because these large urbanized regions with their dense patterns of interaction are hubs of finance, communications, international transport, the global corporate sector, the publishing industry, fashion, and mass culture (Friedmann 1995). These cities are in effect the key nodes in an increasingly networked global economy (Castells 1996). They owe their position to the "spatial dispersion" and internationalization of production. The reorganization of the financial industry also has led to rapid increases in the already significant concentration of financial activities in these cities. Finally, the reconcentration of a considerable component of foreign investment activity and the formation of an international property market in these cities have further fed the economic core of high level control and servicing functions (Sassen 1991).

There are significant commercial advantages to becoming a world city with many regional aspirants such as Hong Kong, Miami, and Sao Paulo, but only a few with reasonable long-term prospects. One such candidate is Shanghai (Friedmann 1998, p.34-35). In this paper, we first briefly explore the makings of a world city and identify certain necessary ingredients. We then examine Shanghai's recent development. Thirdly, we indicate the kinds of policies, devised by both the national and municipal governments, that would enable Shanghai to graduate from being a national to a regional —and possibly, in the distant future, a global hub. And last we show how such policies are being implemented in Shanghai. 


\section{World Cities}

We start with the three premier cities-New York, London, and Tokyo-and ask what is distinctive about their past history, economic environment, and geographical location. How did they acquire their current status?

All three are the financial and cultural capitals of industrialized countries that are key players of the world economy. Taken together, the three countries account for close to half of global GDP and are hosts to the world's 20 biggest companies (by market capitalization), 22 of the 50 largest banks, and 24 of the 25 biggest securities firms (Wall Street Journal, Supplement on World Business, 27 September 1999). Thus, the current size of the economy or-as is the case of the U.K.-its worldwide preponderance in the not too distant past, is one reason for the salience of these cities.

All three cities enjoy a favored location within their respective countries. Their economies are intertwined with and benefit from a rich, diversified, and populous industrial hinterland. The neighborhood is both a source of economic strength but also a source of competitive pressure. A vast market provides the demand and the aggressive competitors that spur continuing dynamism. Although world cities have seen their fortunes fluctuate over the past 50 years - particularly New York-on balance they have pursued policies enabling them to maintain their historically determined positions at the top of the urban hierarchy (Abu-Lughod 1999).

All three cities derived a large measure of their past impetus from a broad industrial base and their role as regional-or national--transport hubs. But in the past three decades, each city has relied on the growth in demand for producer services (e.g. financial and management services) and generalized consumer services, while retaining some manufacturing activities- 
Tokyo is ringed by industry. Finance, other producer services-including research, insurance, accounting, and publishing - the entertainment industry, the medical sector, and education services are now the principal employers and the drivers of metropolitan prosperity in all three cities. The fruitful interaction and growth of the finance and the corporate sectors have been especially critical to the continuing dominance of these cities. This has also positioned them to reap the full benefits of the communications revolution from regional networking and from globalization (Clarke and Gaile 1998). For instance, New York has become the location of a "Silicon Valley" comprised of companies specializing in multi-media software, creating Web sites, and online entertainment and related services.

Among the most remarkable developments during the past two decades is the explosive increase in computing power and the marrying of this capability with the equally dramatic expansion in communications capacity (Friedman 1999). The two together have transformed and globalized the financial system, and they have vastly enlarged international production networks and helped increase the efficiency of supply chain management. These networks have dispersed sequential production processes across national borders so as to reduce costs, improve market access and enhance competitive advantage. In the process, they have boosted crossborder trade, which tends to be managed from a few global or regional hubs (World Bank 1999a).

By being among the first to exploit the commercial opportunities offered by communications technology, the world cities have strengthened their position as financial hubs. ${ }^{2}$ In fact, because 80 percent of all international data transmission relates to financial transactions (Graham 1999), investment in communications technology has enabled these cities to become the corporate nerve centers of globe-spanning production networks. Modern communications 
have made it far easier to manage dispersed business operations from centrally located headquarters that have access to a wide range of vital producer services. After experimenting with the dispersal of headquarters to secondary cities, where commercial real estate and housing costs are lower, most large corporations have found it advantageous to locate in the main urban centers in order to have full access to the desired mix of services. London, for instance, has the largest share of international business in areas such as cross-border bank lending, foreign exchange, and over-the-counter derivatives. While a trading culture of long standing has certainly contributed, London also owes its position in these contested markets to a benign regulatory environment and the quality of professional and support services.

Buttressing all of these attributes is the strength of market institutions and economic openness in all three countries. Legal and commercial institutions have provided the foundations for a thriving financial system and a robust corporate culture. But it is the openness that has served as the keystone: providing the traffic in ideas that have contributed to the many faceted commercial and cultural development of these cities, creating the vibrant milieu that attracts talented people, and providing workers the incentives to both explore and exploit technological possibilities. Recent research has linked openness with the spirit of inquiry, fruitfulness of research, entrepreneurial drive, the growth of trade, the speed of financial innovation, and cultural fruitfulness that stimulates change (Landes 1998). World cities draw upon a range of economic, geographical and institutional strengths, but in addition they rely upon the energies released by openness. 


\section{The Chinese Context and the Future Role of Shanghai}

Shanghai's prospect for acquiring the status of regional hub is undoubtedly tied to China's future development. Can China-a low-income country where about 70 percent of the population still lives in the rural areas-provide the conditions for Shanghai to be comparable to Hong Kong (Enright and others 1997)? Among the East Asian regional centers, Hong Kong will retain an edge for at least several reasons. It enjoys the locational benefits that derive from it being at the intersection of Chinese and foreign social networks mediating the flow of capital. This is an advantage acquired over more than a century during which social relations were bolstered by formal institutions (Meyer 2000). Hong Kong is the most centrally located city relative to the other capitals in East and Southeast Asia. Moreover, if in the future, Asia's economic center of gravity shifts more to the southeast and the south (the clustering of high-tech industries in Guongdong and Fujian is a magnet), then cities like Hong Kong and Singapore are better positioned to service emerging demands (Kuroda 2000, Ochi 1997). The growing significance of scale and network economies associated with key producer services suggests that regional hubs will remain few in number. In addition, there are large gains from the agglomeration of corporate and service activities in a handful of centers offering ample, multilayered opportunities for face-to-face contact, learning, and knowledge spillovers.

But this is not to say that the number of global and regional hubs will remain fixed. New regional centers could emerge as East Asia continues to develop and urbanize. As one of the most rapidly urbanizing countries in the region, China will experience the profound impact of urbanization on economic growth, the pattern of demand, income distribution, and a range of services. By one estimate, about a tenth of China's growth since 1980 can be ascribed to the effects of agglomeration economies. Moreover, urban Chinese hold 70 percent of the country's 
wealth, command incomes that are three times the rural average, and generate much of the demand for new consumer goods coming onto the market ("What the Chinese Want," Fortune, 11 October 1999). Furthermore, China's trade prospects, largely determined by urban centers, and the capacity to generate resources, give it a commanding lead over other countries in the region.

Often called the "crucible of modern China," Shanghai entered the stage of modern commercial and industrial development in the second half of the $19^{\text {th }}$ century (Wei 1987). ${ }^{3}$ During its golden age in the 1920s, with a population over 2 million, Shanghai was "a meeting ground for people from all countries, a great and a unique city, one of the most remarkable in the world" (Pott 1928, p.1). The incursion of western mercantilism into this semi-colonial city and the establishment of China's first modern institutions of higher learning made it the financial and cultural center of the Orient. Ranked as the $7^{\text {th }}$ largest city in the world in 1936 , no modern Asian city from that period could "match Shanghai's cosmopolitan and sophisticated reputation" (Yeung 1996, p.2).

Today, with a resident population of 13 million and land area of 6,377 square kilometers in the metropolitan area, Shanghai is the biggest of three cities - the two others are Hangzhou and Wuxi-that together comprise the principal urban region in China (see Map 1). ${ }^{4}$ The metropolitan area, governed by the Shanghai Municipal Government-equivalent to a provincial government because of Shanghai's special administrative status-consists of 15 urban districts (10 of them are located in the central city) and 5 suburban counties (see Map 2). Continuing efforts of decentralization have offered district governments substantial autonomy in tax collection, budget allocation, infrastructure provision, and planning. 
Shanghai, with a GDP of $\$ 49$ billion, has a per capita income of $\$ 3,712$ (current dollars in 1999), a highly diversified industrial base responsible for 5.5 percent of national industrial output, and an expanding services sector (see Table 1) offering agglomeration economies (Business China, 11 September 2000). But only a fraction of such economies have been fully exploited because of the persisting compartmentalization of industrial subsectors and research facilities, and a resilient legacy of a socialist planning system now being displaced piecemeal by the market system. After a decade of industrial restructuring, municipal authorities are paying closer attention to the development of high-tech products and six manufacturing subsectorsautomobiles, telecommunications, power station equipment, steel, petrochemicals, and home appliances (Shanghai Star, 28 May 1999)..$^{5}$ At the same time, the share of services has begun rising steeply since 1993 and now accounts for 48 percent of municipal GDP.

Entering the $21^{\text {st }}$ century, Shanghai is a city competing aggressively for the mantle of China's premier metropolis in the face of competition from an established center-Hong Kong, and other aspirants such as Beijing. Its share of the nation's GDP is almost twice that of Beijing, and its growth (averaging 9.5 percent in 1999-2000) is the highest of any city in China. In Shanghai's favor is the support and incentives it has received from the central government. The attention given to Shanghai represented in part the attempt by the center to promote development in the northern part of the country to balance the rapid advances taking place in the southeastern region (Ochi 1997). Pudong, a newly developed area on the eastern side of the city, provides Shanghai with an abundance of commercial and industrial space supported by good physical infrastructure, all constructed since the early 1990s (see Wu 2000). Moreover, Shanghai has invested heavily in transport facilities and the latest fiber optics based on communications 
technology so essential for the growth of local producer services and for integrating with the international business community (Wu and Wong 1997).

Around Shanghai and extending westward along the Yangtze River Valley is one of the two most prosperous economic hinterlands in China with an urban population of 200 million and a GDP of nearly $\$ 300$ billion (1995 dollars at market prices). ${ }^{6}$ The southeastern region, comprised of Hong Kong and the Pearl River Delta, has registered equivalent growth rates and has a superior transport and communication facilities. But the size of the Yangtze Basin economy, its momentum during the 1990s, and its contiguity to the Qingdao-Yantai-Jinan region are certainly impressive. When we look into the future, the pattern of development in the Yangtze Basin, the productivity of the diversified agricultural economy, the vast scale of rural industrial activities, and the speed with which transport and communications infrastructure are being built up, all suggest that this region competes strongly with other parts of the country. ${ }^{7}$

Preeminence in a national context, however, is only one of several attributes of a regional or global hub. Actions enabling Shanghai to acquire the status initially of a regional center would need to encompass at least two strands: the first involves greater openness, comparable to that enjoyed by Hong Kong. This is primarily in the hands of the central government. The second calls for municipal policies to enhance Shanghai's competitiveness as a metropolitan area.

\section{Pathways to the World City-Greater Openness}

\section{Economic liberalization}

Relative to many other countries, China remains a closed society where central and subnational governments regulate and limit contacts with foreigners, control movement into and 
out of the country, regulate Internet traffic, and take a minimalist view of individual rights vis-àvis the state. ${ }^{8}$ The political system is firmly in the grip of the Communist Party. And although the Shanghai municipality, with the status of a province, enjoys substantial fiscal and administrative autonomy, it is subject to the same strictures as the rest of the country regarding relations with the outside world.

By containing links with the rest of the world, the Chinese authorities make it harder for Shanghai to capitalize on foreign direct investment (FDI) in infrastructure building, international production networking, and the growth of producer services. Although Shanghai's rapid development over the past decade has contributed to its continued national dominance, key elements of national policy have kept Shanghai from moving closer to the ranks of cities that can claim to be regional hubs. China's limited attractiveness for the international business community, which affects the prospects of its cities, was underlined by an Economist Survey ( 7 March 1998, p. 114). Hong Kong had a score of 8.5 out of 10 during the period 1992-96, ahead of Britain, the Netherlands, Singapore, Canada, and the United States. China was not among the top 30 countries.

Openness has many dimensions, including trade, the legal framework, finance, and culture. China's accession to the World Trade Organization (WTO) will result in a significant liberalization of trade through the adoption of rules and incentive mechanisms shared by other members. ${ }^{9}$ It will involve China directly in international governance associated with trade and related issues. It is also likely to result in a far-reaching dismantling of barriers to trade in manufacturing, agricultural products, and many kinds of services and far greater penetration of foreign entities in the financial sector, telecommunications, and other areas. ${ }^{10}$ These would 
accelerate the reform of the state enterprise sector currently being downsized through closure, merger, or privatization.

Improved communications with other countries is another dimension of the move towards openness. This already is being pursued with great vigor through heavy investments in telecommunications, amounting to $\$ 400$ billion between 1994 and 2000 , which has provided fixed and mobile telephone service to more than 155 million users. ${ }^{11}$ The number of Internet users is expected to reach 33 million in 2003, as against 8.9 million in 1999 and 16.9 million in June $2000 .^{12}$ For this investment and the inter-linkages it provides to yield their full returns, domestic rules and laws will have to evolve to recognize individual freedoms to use the burgeoning channels of communication. ${ }^{13}$

This leads to a third and related aspect of openness, which is the framework of commercial laws and regulations governing business dealings and financial transactions. Starting in the mid-1980s, China has been gradually building a legal infrastructure, training lawyers, assimilating laws, and instituting legal procedures that are increasingly a common currency worldwide. B $\mathrm{s}$ the nature of Chinese legal and regulatory practices, as well as the approach to enforcing regulations, still differs markedly from that of more open industrialized countries. For example, there is legislation providing redress where administrative power is misused, but only under certain conditions when the government is involved, and no redress is available when the Party is involved. The courts cannot challenge the right of the police to impose administrative punishments and send people to jail without a trial. ${ }^{14}$ This can result in uncertainty, inhibits business dealings, and raises transaction costs, especially for foreigners. China's vast potential market tempts foreign companies and financial houses and is responsible for cumulative foreign investment in China of about $\$ 325$ billion (committed 
amount) by the end of $1999 .^{15}$ But the lack of transparency and the problems of coping with complex local regulations are a serious disincentive. The persistence of high transaction costs resulted in a reappraisal of business opportunities in China by many foreign corporations and a slowdown of FDI in 1999 (“China Survey," Financial Times, 1 October 1999). ${ }^{16}$ Hence, narrowing the institutional gulf in legal and regulatory matters between China and other countries will be a key aspect of greater openness.

China remains largely segregated from international financial markets. Earlier plans to liberalize transactions on the capital account were interrupted by the East Asian crisis of 1997-98 that battered five countries in the region but left China largely unscathed. In the immediate aftermath of the crisis it was thought that China avoided succumbing to the crisis because it deferred the deregulation of the capital account until it had built up adequate supervisory capability and thereby contained the inflow of short term and, portfolio capital. Malaysia's experience with controls on capital outflow also lent credence to this line of thinking. However, closer analysis of the entire crisis episode and of the use of capital account controls not just in East Asia but also in Latin America suggests that the story is much more complex and capital controls may have had much less of bearing on vulnerability than the state of the financial systems in the crisis-hit East Asian economies and their neighbors. ${ }^{17}$

The experience of East Asia and Latin America seems to have established some new findings and reaffirmed old lessons: there is no significant relationship between the openness of the capital account and economic volatility (Easterly, Islam and Stiglitz 1999). However, the capital account should be fully liberalized only after achieving macroeconomic stability, ensuring that the banking system is strong and competitive and putting in place an effective regulatory system (Cooper 1999). Where countries delay needed banking reforms and use this as 
a reason to defer capital account liberalization, urban development suffers, the deepening of financial markets is significantly slowed and much capital is allocated inefficiently. Producer services develop less rapidly and financial repression also affects the cost and access of small businesses to capital. All of these are likely to influence longer-term growth (Levine 1997).

A major challenge for China during the medium term is to strengthen the financial system (Newfarmer and Liu 1998). As markets become more sophisticated, new derivative instruments appear, and trade contacts continue to expand, restraining capital outflow is likely to prove extremely difficult and even containing inflows would pose problems. Thus capital controls are likely to inflict transactions costs, and raise borrowing costs for small and medium scale enterprises without achieving many tangible benefits in terms of protection from major shocks (Edwards 1999). If they reduce the pace of banking reform they could involve a substantial waste of resources. $^{18}$

\section{Strengthening market institutions}

Shanghai is embarked on the road to becoming a financial center, but it lags far behind Hong Kong. So far the central government and the municipal authorities have taken only the first few steps by creating some of the physical infrastructure and inviting international financial entities of all kinds to establish offices in the city. Commercial banks, investment and brokerage houses, insurance firms, other market makers, and telecommunications companies have

responded by establishing footholds in the city. ${ }^{19}$ In all, 52 foreign banks had established offices or commercial operations by the end of 1998. But thus far, the authorities have restricted retail banking activities, securities trading, and insurance. Foreign banks can only make local their currency loans to multinationals and joint venture partners, and raise capital for Chinese 
companies only in offshore markets. Many other elements must be put in place-for example, permitting foreign intermediaries to compete for local deposits and services such as credit cards and home mortgages - before Shanghai becomes even a regional crossroads for the international financial community (Chowdhury 2000). ${ }^{20}$

One of these is the lowering, as is proposed under the soon to be adopted WTO rules, of barriers to trade- a step that would promote trade, sustain growth, and lead to a continuing decline in poverty. Second is the opening of China's capital account, which, along with full convertibility, would permit the freer flow of capital in and out of the country. A third is a framework of rules and laws governing financial and other entities that delineate and enforce rights in a transparent and predictable manner, especially those pertaining to contracts, intellectual property, bankruptcy procedures, and foreclosure. Fourth is a regulatory framework to monitor activities, build the institutions that will ensure stable market functioning and induce innovations conducive to growth as well as efficiency. Fifth, is the reform of financial entities to enhance their autonomy and efficiency and enable them to compete against foreign organizations, a development that would permit a gradual dismantling of the many curbs on the activities of foreign firms, including investment in Chinese banks. In 1999, the nonperforming loans (NPLs) of the four major state banks amounted to at least a fifth of their loan portfolios. Furthermore, as state controlled banks channel over 75 percent of bank credit to state enterprises, half of which have been making losses during 1998-99, the percentage of NPLs is likely to increase. Return on assets in the banking system was less than 0.2 percent in $1999 .^{21}$

The final element relates to the continuing development and deepening of the financial and insurance markets, a process that has been ongoing since the early $1990 \mathrm{~s}^{22}$ Markets for stocks, other financial instruments, and foreign exchange are now functioning in China, along 
with adequate mechanisms for clearing transactions and settling payments. Over 1,000 state enterprises are listed on either the Shanghai or the Shenzhen stock exchanges by 2000 and market capitalization is approaching 4 trillion yuan $\left(\$ 484\right.$ billion). ${ }^{23}$ But the insurance industry is still woefully underdeveloped. The institutional base created must evolve much further before China can attain parity with other industrializing countries not to mention the advanced economies. Shanghai has a head start in the sphere of financial market development in China, which is meaningful in a national context but not yet in regional terms. ${ }^{24}$

\section{Pathways to the World City-Competitiveness and Livability}

While the critical policies determining economic openness will be largely decided by the central government, and the prosperity of Shanghai's hinterland will be a function of policies pursued by a host of entities, Shanghai's municipal authorities also have a large role to play in enhancing the city's competitiveness and quality of life. This calls for action in a number of areas, building on a variety of ongoing initiatives. Shanghai is active in each of these areas, but it faces difficult choices and many steps may involve complex negotiations with the central government as well as neighboring provinces. This section outlines some of the progress Shanghai has made and likely hurdles it will face, including:

- A coordinated development of transport, housing, and infrastructure to minimize congestion and improve urban livability, through organizational streamlining and the use of new financial instruments.

- Industrial consolidation accompanied by land use policies inducing a shift of industry away from the core areas and permitting mixed commercial and residential use of prime urban land. 
- Taking measures to ensure an adequate supply of entrepreneurship, skills, and labor from within the municipality and through migration.

\section{Renewing urban infrastructure}

Shanghai's determination to renew itself can best be seen in its effort to overhaul the city's aging infrastructure since the early $1990 \mathrm{~s}^{25}$ Unmet demand is shrinking as Shanghai makes progress in virtually every infrastructure service (see Table 2). Improvements are particularly rapid in road construction, park expansion, and wastewater treatment. Shanghai now treats 30 percent of its wastewater, compared to an average level of about 7 percent in all Chinese cities. A number of large infrastructure projects have been completed, such as three bridges and two tunnels across the Huangpu River, an inner ring road, elevated north-south and east-west throughways, and two new subway lines. ${ }^{26}$ Furthermore, the first phase of a new light rail system is expected to be operational in 2000 . The city recently unveiled a 20 -year blueprint for the construction of 11 subway lines, seven light rail lines, and three suburban railways. So by 2020 , the city will have a total of 325 kilometers of subway and 136 kilometers of light rail (Shanghai Daily, 19 June 2000).

Enhancing its external linkages has been a key objective of infrastructure building in Shanghai. Most of all, the new international airport that opened in September 1999 marks a significant step in the city's long-term goal to become an aviation hub in the Asia and Pacific region. $^{27}$ It will be connected to the planned Beijing-Shanghai expressway by a proposed highspeed railway supplemented by high-speed ferries running from a terminal adjacent to the airport to nearby ports in Zhejiang province (Shanghai Star, 19 March 1999). Foreign airlines have responded to the city's rising significance as a business center and the growth in airport capacity 
by increasing the volume of service. In 1999, several new, non-stop flights were added, including KLM Royal Dutch Airlines to Amsterdam, Austrian Airlines to Vienna, and China Eastern Airlines to Japan's Fukushima. Shanghai now has non-stop flights reaching most of the world's important urban centers. Rapidly increasing Internet usage also relates to the export orientation of Shanghai-based enterprises and the steadily improving quality of the telecoms facilities is helping integrate Shanghai with the world economy. Greater broadband access and the use of mobile technology, as in Singapore and Japan, will enhance the utility of the Internet although this will require resolving some thorny issues regarding standards, technology, and links with households and freedom of access. ${ }^{28}$

Investment in infrastructure services has increased steadily, with a greater emphasis on city streets, sewerage systems, and other municipal works (see Table 3 ). The infrastructure sector now receives the level of attention from the municipal government it deserves and accounts for about one-tenth of Shanghai's total fixed asset investment. ${ }^{29}$ Much of Shanghai's success in renewing infrastructure can be attributed to a comprehensive program of resource mobilization and expenditure management beginning in 1990 (Yusuf and Wu 1997).

First, municipal authorities have increased user charges for some infrastructure services including bus fares, gas supplies, water, wastewater discharge, and municipal sanitation services. Second, Shanghai has begun to raise funds by leasing land, in the process attracting a large volume of FDI into real estate development including commercial and apartment complexes catering to foreign companies (Wu 2000). Shanghai's population density, its relative prosperity, and the nature of commercial development now underway, means that real estate in the municipality is extremely valuable. This has induced many state enterprises to move their factories out of the downtown areas and lease the land for commercial purposes ("China's Land 
Grab," Far Eastern Economic Review, 13 April 2000). Third, the city has set up separate transport and energy funds in municipal revenue collection, guaranteeing much of the funding for the two sectors. Last, since 1986 Shanghai has tapped into the international market to lure direct investment and build-operate-transfer schemes. ${ }^{30}$ The issuing of domestic construction bonds also has been growing steadily, capturing the high level of household savings.

In addition, progress in infrastructure building would not have been possible without large-scale organizational reforms. As a part of Shanghai's reform to unify financial and administrative responsibilities for municipal bureaus, the Shanghai Urban Construction Investment and Development Company was formed in 1992 to mobilize, allocate, and manage funds for urban construction. Displaying an impressive record of achievement in infrastructure financing since its creation, this state-owned company has employed a wide range of financing mechanisms, particularly through such non-state channels as construction bonds, the stock market, and service concessions. It has entered into concessions with non-state enterprises to operate the bridges and tunnels across the Huangpu River. It also has established a number of subordinate entities, mainly in charge of water supply, which are listed on the Shanghai Stock Market (Wu 1999b). Available official information shows that in 1995 and 1996, funds mobilized by the company accounted for about 76 percent and 90 percent, respectively, of Shanghai's total urban infrastructure revenue.

Another important element of Shanghai's institutional reform is greater managerial autonomy for public utility agencies. To the extent feasible, municipal service departments have been given full responsibility for planning, investment, operations, and maintenance. These departments also are adopting an independent cost-accounting system to facilitate sector management and financing. For instance, a sewerage company has been created to maintain the 
newly constructed sewerage system. A major reform materialized in 2000 when the city consolidated water and urban transportation functions-scattered across up to nine different municipal agencies in the past-into two bureaus that would have full authorities over decisionmaking, operations and maintenance (China Daily, 15 May 2000). Other avenues, which would allow enterprises serving as contractors to provide selected services, are under consideration and some bus services are already under concession. The city is also commercializing some of its waste disposal business and a company from neighboring Jiangsu Province has won the contract to collect garbage, a job shunned by many locals (Shanghai Star, 24 July 1998).

Substantial progress has been made in raising the supply of better quality housing since the early 1990 s through heavy investment (increasing from 2.6 billion yuan in 1990 to 43.3 billion in 1997, Shanghai Statistical Bureau 1998). The city is replacing 3.6 million square meters of endangered structures and shanty apartments, mostly in the old central city. The accessibility of housing to the average family is on the rise as a result of reforms, among the most comprehensive in the nation (Wu 1999a). The city, employers, and employees all contribute through a newly established public reserve fund to finance housing purchases over time. Since 1998, all banks have been able to supply mortgages to qualified homebuyers on behalf of the public reserve fund. In addition to new home purchases, many people have bought property or use rights to the homes they were assigned under the old welfare housing system and some also trade such rights on the secondary housing market to acquire better housing. ${ }^{31}$

The creation of a mortgage finance market, the assignment of leasehold rights, and the permission to trade in the secondary market are important steps in housing reform. But the coverage remains fairly restricted, the residential property market is insufficiently differentiated and collateral requirements enforced by banks are strict, while the credit provided is relatively 
short term ("China Survey," Financial Times, 1 October 1999). Further reforms will be required to ensure that the large volume of public sector housing is properly commercialized by granting property/lease rights to current residents and the remaining publicly-owned welfare housing is adequately maintained. ${ }^{32}$

Further institutional reform also will be needed to minimize political pressures on infrastructure providers, giving them sufficient autonomy to collect fees, make price adjustments, undertake service planning and have incentives to assume full financial responsibility. Public agencies still have a long way to go in devising appropriate commercial rules and encouraging private participation and competition. Permitting majority private shareholders in infrastructure construction or wholly private infrastructure facilities is unlikely in the foreseeable future unless underwritten by build-operate-transfer schemes. And the private sector may be hesitant to incur greater responsibility and risk as investment in infrastructure provision is usually for a significant duration and the period of implementation can affect investment return. Private interests, therefore, may be better utilized in the areas of infrastructure operation and maintenance, with public transportation, waste disposal, and sanitation services as prime candidates.

\section{Creating new space of production for industrial consolidation and investment promotion}

Helping Shanghai to plant industrial roots a century ago, foreign investment is now a major force pushing the city ahead with systematic change. By 1998, the stock of utilized foreign investment reached US\$38.6 billion, of which about US\$6.3 billion involved technology imports (Shanghai Statistical Bureau 1999). FDI volume has grown rapidly, accounting for about three-quarters of all international investment in 1998. Because of its industrial depth, modernizing infrastructure, and skilled workforce, Shanghai has outpaced other Chinese cities in 
the race to attract FDI. ${ }^{33}$ A return on capital investment, 2 percent higher than the national average ( 8 percent) is an additional inducement. The city is also courting more investors from the United States and Japan, while experiencing a decline of FDI originated in Hong Kong (see Table 4). Funding from overseas sources has been instrumental in the building of the city's new subway system, new industrial districts, and the hotel and other facilities needed to attract large numbers of businesses and tourists (Wu 1999b, Wu 2000). Shanghai's strategic location and external linkages, on the other hand, also lure domestic firms to invest in the city and use it as a springboard to the world market.

Reflecting the city's drive to rejuvenate its mature industrial base, manufacturing sectors are attracting more foreign investors. As of July 2000, 254 of the Fortune 500 companies have invested or established offices here (China Daily, 18 July 2000), and the chief examples are Alcatel, Volkswagen, General Motors, NEC, DuPont, and IBM. This could be a prelude to the shift of some regional headquarters functions to the city. The largest gains in output value are registered in such rising industries as telecommunications equipment, integrated circuits and computers, bio-medical technologies, and new materials (Shanghai Statistical Bureau 1999). Shanghai is likely to regain its industrial edge and competitiveness through these industries as products from its traditional light industries (e.g. electronics, textiles, and garment) have been losing ground in domestic markets. Efforts also are taken to revamp the textile and garments industries through attracting more brand name fashions from overseas, and a series of international fashion exhibitions has been organized for this purpose.

Since the early 1990s, Shanghai's has been actively promoting investment in services, with the backing of the central government. Foreign insurers have been allowed to operate only in Shanghai, and all nine foreign banks currently licensed to deal in the domestic currency are in 
Shanghai's Pudong New Area (Asahi Evening News, 4 June 1999). The traditional face of the city's food markets and department stores also is being altered by international companies. Deals jointly financed by funds from Hong Kong and Taiwan are helping Shanghai to rejuvenate its motion picture industry, which gave the city the title of Hollywood of China in the 1930s. ${ }^{34}$ FDI in the tertiary sector, however, appears to be stabilizing although the real estate sectors continue to attract a substantial amount (see Table 4).

To appeal to foreign investment and international businesses, several new industrial districts (often called Economic and Technology Development Zones, ETDZ) have been created since 1984. Special regulations comparable to those offered by other coastal provinces have been extended to these districts: tax exemptions for enterprises doing business with foreign companies for a limited duration, tax holidays for new factories set up with foreign investment, and exemption from import-duty for production materials used by these facilities (Wu 1999a). To ensure broad-based future development, the city is also strengthening the industrial, science, and technology capabilities of the new districts. The existing stock of FDI and the quality of services is gradually strengthening Shanghai's bargaining position vis-à-vis foreign companies, enabling it to press for joint ventures, local contracting and technology transfer (Yeung and $\mathrm{Li}$ 1999).

The Pudong New Area is the focus of the effort to produce for the international market. The designated space is a triangular area adjacent to and east of the central city, stretching from the east bank of the Huangpu River to the southwest of the Yangtze estuary and covering over 522 square kilometers. Planned for a three-phase development, Pudong is designed to relieve the spatial pressure on old Shanghai. It already contains China's largest free trade zone, a fully operational export processing zone, a high-technology development zone, ${ }^{35}$ the new 
administrative center for the Shanghai municipal government, and a large number of new residential communities. The modern facilities - and the concessions--in Pudong have already attracted many businesses. Baoshan Steel Corporation, China's largest steel conglomerate, has put up a facility. The largest department store in Asia has been built here, with investment from the Japanese retail giant Yaohan. And a JS\$2 51 ilion General Motors facility has been turning out Buick cars, the second major joint aurs production line in Shanghai.

Pudong also provides Shanghai with a new central business district (CBD) that can house a variety of business activities and, most importantly, financial and business services that are the backbone of other major world cities. The traditional commercial centers of the city are formed by two avenues, Nanjing Road and Huaihai Road, which are already approaching saturation as redevelopment proceeds in downtown. The building of Pudong's Lujiazui CBD- an area of 1.7 square kilometers on the east bank of the Huangpu River-has been guided by the long-term ambitions of the city and facilitated by an international consultative planning process in which experts from France, Britain, Italy, and Japan participated (Olds 1997). A host of financial institutions, corporate headquarters, as well as commercial and cultural activities are being housed there, including the Shanghai Stock Market and about a dozen foreign banks-the only area in the country where foreign banks are allowed to have regular business operations by the central government.

Competing with Pudong are the Minhang ETDZ, Hongqiao ETDZ, and Caohejing HighTech Park, all located to the west of the central city. With more specialized functions, these zones have sought niches in such modern industries as electronics, medical equipment, computers, telecommunications, bioengineering, aerospace and precision instruments, and new construction materials. Although these zones have been more successful than past efforts of 
creating satellite towns, a large proportion of Shanghai's industrial base still remains in the central city districts (Gaubatz 1999). This is in contrast with Beijing where industrial activities are being concentrated in the outer suburbs.

Additional measures need to be put in place to consolidate and relocate industry out of downtown locations. Apart from being a source of congestion and environmental pollution, these factories contribute to the inefficiency of land use. In any case, many are highly inefficient operations that deserve to be shut down. To solve problems associated with fragmented industrial land use, Shanghai has largely relied on relocating factories from the central city to the new industrial districts available for expansion. Between 1991 and 1998, about 12,000 work units as well as 400,000 households were moved from downtown to the city's outskirts (Shanghai Daily, 1 September 2000).

The rationalization of land use and the utilization of the new industrial estates, however, will not proceed smoothly unless the prevailing system of land allocation and charges is changed. Land lease awards need to be made through auctions with standard lease terms and payments rather than being assigned through negotiation. Land values, therefore, are determined through competitive and transparent auctions and not by public authorities. Evidence from a few cities, including Shanghai, suggests that central city factories could fully finance redevelopment if they were permitted to sell their land to real estate development corporations through competitive bidding procedures (Dowall 1993).

Caution needs to be exercised as the new districts will inevitably compete with the central city for resources. It may be wise to prioritize their development as competition among them is not necessarily conducive to growth. The challenge also lies in pursuing specialization without foregoing the benefit of agglomeration. Shanghai's development funds will be insufficient if 
they are spread too widely and may be wasted in premature over-building. This is already evident in parts of Pudong where many new residential and commercial buildings remain vacant, largely the result of significant mismatches between supply and demand. ${ }^{36}$

Shanghai's property development is yet to be regulated by either a functioning land market or sound planning. ${ }^{37}$ Many foreign investors appear not to be disturbed by the high vacancy rates in Shanghai's office and luxury housing markets, largely due to the belief that more overseas and provincial funds flowing into the city will continue to push the economy forward. Enthusiasm of city officials to benefit from selling land rights and to lure foreign investment has only made the bubble expand. The use of real estate business as the key to the rebuilding of the increasingly depressed domestic market (seen in the late 1990s), as promoted by China's Premier Zhu Rongji, also makes it difficult to put a break to new housing construction. Municipal authorities have tried to play down the vacancy problem as the natural cycle of property market, although the approval of new office projects was suspended in mid1999 (Shanghai Star, 7 July 1999). It is clear that the creation of more commercial space may subject Shanghai to an increasing degree of market speculation, similar to that seen in urban centers of Southeast Asia during the 1997-98 crisis. Then in mid-2000 in a bold step to prevent such a possibility, the city enacted a new regulation that would deprive all district and county governments of the approval right of land leasing. Instead the Shanghai Municipal Housing and Land Administration will have the sole authority, and stop the leasing approval of land for such projects as shopping malls, entertainment centers, golf courses, and grade A villas and office buildings (Shanghai Star, 4 August 2000). 


\section{Labor market prospects}

While policy, infrastructure, and investment are certainly important, successful cities draw their energy from entrepreneurial dynamism and the quality of the workforce. In an economy with accelerating technological innovations and rising specialized service functions, the labor force needs good basic education and skills, and market institutions should permit a high degree of flexibility. Measures to ensure an adequate supply of entrepreneurship, skills, and labor will be one of Shanghai's biggest challenges as its state enterprises move away from the practice of providing the workforce with tenured employment and guaranteed pensions along with health, housing, and other benefits.

The foremost challenge is relocating workers displaced by the large-scale closure and divestiture of state enterprises, which is particularly difficult for middle-aged workers close to retirement in the city's core industries like textiles. Labor use in these enterprises is highly compartmentalized with workers trained in a narrow specialization. Therefore, the retraining of workers, either for reassignment within their enterprises in response to production shifts or to facilitate employment after closure, greatly influences internal and external labor mobility. For the moment, the city has opted for the absorption of surplus workers in low skill service operations where job prospects have multiplied and retraining is minimal. Specifically, these workers find employment in retail, repair and maintenance works, grounds maintenance, household services, and cleaning services.

Shanghai's workers command a wider range of skills compared to other industrial cities in China, but the share of professional and technical personnel lags far behind key global centers. Shanghai has begun to address this educational gap and two measures have been taken to attract 
new, young talent into the city. Enrollment for local students in universities and colleges, as well as in vocational schools, has been increased substantially. ${ }^{38}$ Shanghai also has relaxed restrictions on enterprises in hiring personnel with college or graduate education from other parts of China by allowing them more quotas for urban household registration. In particular, the city welcomes students who are returning from overseas, either temporarily or permanently, to open new businesses.

The rapidly aging population presents Shanghai with another difficult challenge. Those over age 65 accounted for 12.5 percent of the total population in 1996 and 13.3 percent in 1998 , and on current trends are expected to account for 26 percent in the year 2020 (Shanghai Star, 5 June 1998). Shanghai now ranks uppermost among Chinese cities in aging population, about 20 years ahead of the national trend. It is perhaps the only city in China that is witnessing a phenomenon similar to that occurring in countries with substantially higher income levels. A growing number of retirees demand a better pensions, housing, and medical benefits.

The significant growth in the share of old age cohorts in the population is partly the result of a low birth rate. As the one-child family planning policy has been fairly effective in large cities, natural growth of the population was only about 0.35 percent in 1990 and -0.23 percent in 1996 (Shanghai Academy of Social Sciences 1997). At the same time, life expectancy for men has risen from 71 years to 75 years, and for women from 74 years to 79 years between 1969 and 1998 in Shanghai (Liberation Daily, 29 July 1999). Much of the growth of the resident population between 1985 and 1995 can be traced to the return of Shanghai-born youth, displaced during the Cultural Revolution (1966-1976).

The projected decline in the city's workforce can be offset by an increasing volume of migrant workers, as is the case elsewhere in the world. ${ }^{39}$ Shanghai is already relying on 
temporary migration (without change of household registration) as an alternative to permanent migration (with household registration change) in meeting its labor force needs. About 3 million . temporary migrants and transients, largely permitted by relaxed migration policies, are now working and living in metropolitan Shanghai, most of whom do not have urban status and are therefore not counted as part of the resident population. Nevertheless, many temporary migrants stay in the city for a prolonged period of time and often with their families. ${ }^{40}$ Without urban household registration, these temporary migrants are denied access to free education, subsidized housing, and pensions. The impact can be severe for migrant families with children. When families of large size migrate together, income disparities between urban residents and migrants also increase (World Bank 1997).

Accommodating migrants and attracting those with the required skills are likely to be a long-term issue facing municipal authorities. This will require a change in the provision of adequate housing as well as services. A new type of housing is becoming available in some areas of Shanghai-migrant housing complexes managed by sub-district and township agencies. Some involve reuse of old temporary housing while others are new residential compounds built by large enterprises. Yet enterprise provided dormitories and private housing rentals are still the most common housing choices available to migrants, in which they live in conditions considerably worse than local residents.

To sustain, let alone improve, the quality of its workforce while preventing social stratification and urban poverty, Shanghai will have to tackle the laws governing migration. Migrant workers and entrepreneurs will provide much of the human impetus for the city's future development. Housing reform, for instance, can help improve migrants' quality of life and prevent slum formation. Specifically, migrants can be allowed to participate in the secondary 
housing market, where apartments are more affordable. Migrants also need greater access to jobs and educational facilities previously open to local residents only. Of course, these measures do not fully address the costs and hardship migrants bear as a result of the household registration system, whose reform will have to be initiated by the central government. It is clear that the current practice of linking household registration and the provision of urban services is likely to widen the rural-urban divide and social differentiation within cities. To properly respond to the need for migration requires that this linkage be discontinued.

\section{Conclusion}

In a globalizing world, cities at or near the apex of the international urban hierarchy are among the favored few that have acquired large economic, cultural, and symbolic roles. As urbanization continues and service activities—especially information technology (IT) and finance related - take on an even greater prominence, the number of regional and global centers could increase, but only if they satisfy some exacting requirements. Shanghai, located in one of the most rapidly developing parts of the world, may well be one of them. If the Chinese economy can sustain its growth rate, it will rival the U.S. in a few decades. And if Shanghai is able to retain its preeminence in the Chinese context, then it is likely to be the East Asian city with the best prospect of becoming a global center.

However, Shanghai's chances depend on the extent to which China "opens up."41 It also rests on a host of municipal policies that focus the municipality's industrial strength, substantially enlarge its base of IT and producer services, ensure an adequate supply of skills, expand the availability of housing and infrastructure services in line with demand, and improve the quality of life. Shanghai is in the vanguard of change in a number of areas, but, as we have 
indicated, the tempo of reforms needs to be sustained. In particular, it needs to nurture an internationally competitive services sector by dint of reform and by attracting FDI. The emphasis on industry, housing, and infrastructure will certainly have payoffs, but so long as the volume and quality of services lag, Shanghai will have difficulty making it into the ranks of regional hubs. Openness, combined with policy measures that induce competitiveness, is most likely to lead to outcomes that are in Shanghai's long-term interests. 
* We wish to thank Josef Gugler, Yue-man Yeung, Xiangming Chen, Deepak Bhattasali, and participants in a National Research Council workshop for their insightful comments.

1 Friedmann defines world city as "a class of cities that play a leading role in the spatial articulation of the global economic system or designate a dimension of all cities that in varying measure are integrated with this system" (Friedmann 1998, p.26.). Sassen (1991) uses the term global city to describe the very same cities - New York, London and Tokyo. She views these cities as nodal points for the coordination of processes and sites of production. Following the stock market collapse in Tokyo in the early 1990 s, the metropolitan administration switched from the objective of a global city to one of becoming a lifestyle city (Gordon 1999).

2 Because Tokyo has lagged behind with its reforms, its role as a financial hub is far less significant. On financial reform in Japan, see Hayes 2000.

3 Many academic volumes have been devoted to Shanghai's past, chief among which are Murphy 1953, Howe 1981, Wei 1987, Johnson 1995, Goodman 1995, and Lu 1999.

4 This population figure includes only registered permanent residents; it is the same throughout the text unless otherwise noted. An estimated 3 million temporary migrants, largely from rural China, also reside in Shanghai. The other major urban regions are Beijing-Tianjin-Tangshan and Hong KongGuangzhou-Shenzhen (Wang 1998 p.265).

5 Shanghai is the leading producer of many items in each of these categories, accounting for nearly half of all sewing machines produced and close to a third of power generating equipment (Yeung 1999).

6 Yeung (1999) notes that the Yangtzi Basin accounts for a third of China's population and 40 percent of GDP.

7 Shanghai is China's largest seaport, accounting for 18 percent of total cargo. The total volume of traffic handled by the Shanghai Port Authority in 1998 was 90.5 million tons, of which 21 million tons was coal and 27.6 million tons was containers. Bulk traffic-coal and fertilizers declined through the 1990s (Shanghai Statistical Bureau 1999).

8 Notwithstanding the fact that total trade is in the region of $\$ 420$ billion (2000), making China the ninth largest trading nation with one of the highest B2B transactions in the world (Pearson 2000).

9 See Martin and others 1999. Recent work by Frankel and Roemer (1999) provides added support for the relationship between trade and increase in incomes. They find that a one percent increase in the ratio of trade to GDP raises per capita incomes by one half percent by stimulating factor accumulation and productivity. The relationship between trade and growth has been noted in cross country studies by Sachs and Warner (1995 and 1997). On China see Yu 2000, Li and Zhai 2000, Yu 1998 and "The Big Lie of Global Inequality," Financial Times 9 February 2000.

10 "China weighs lifting curbs on foreign firms," Wall Street Journal, 10 January 2000; "China to speed up financial reform before joining WTO," Financial Times, 21 January 2000.

11 "Surf's up," Far Eastern Economic Review, 4 March 1999. China surpassed Japan in the first quarter of 2000 as the country with the largest number of cell phone users - 51.7 million (China Business, 11 September 2000). The number of landlines exceeded 100 million in June 2000 (Hartford 2000).

12 "China's Risky Leap Forward," Financial Times, 12 August 1999; "China Survey," Financial Times, 1 October 1999; and Hartford (2000). The number of Internet users in Shanghai rose from 3.3 thousand in 1996 to 102 thousand in 1998. And the number of long distance telephone lines (not all local phone lines can dial long-distance directly) increased from 59,000 to 84,000 over the same period (Shanghai Statistical Bureau 1999, p. 244.)

13 Attempts by the Chinese government to control the use of the internet through closer regulation and the fostering of state owned websites would only slow the process of opening ("Beijing set to step-up curbs on Internet," Financial Times, 22 March 2000, and Kennedy 2000).

14 "China: The Legal Environment," Oxford Analytica, 29 July 1998; "China: Rule by Law," Oxford Analytica, 25 October 1999. 
15 "Turning Point," Far Eastern Economic Review, 31 August 2000.

16 During the first eight months of 1999, contracted foreign direct investment fell by 20 percent over the previous year to $\$ 25.3$ billion ("China: Global Engagement," Oxford Analytica, 21 December 1999). However, inflows rose in 2000 and are expected to reach $\$ 45$ billion (China Business, 17 July 2000).

17 Poorly managed, and lightly supervised banks in some of the East Asian countries invested their resources without due analysis of risk often in sectors favored by the government, in affiliated businesses or in real estate. This gradually increased the proportion of non-performing assets and implicitly enlarged the contingent liabilities of the government. As awareness of this banking fragility became more widespread and doubts grew as to the ability of governments to rescue the banking sector, a silent flight of capital commenced. A succession of events then precipitated a full-fledged crisis. Even China was not immune to this silent flight, reflected in the country's large errors and omissions in the balance-of-payment accounts.

18 Nonetheless, with capital flowing back into the East Asia region and financial reform still in its early stages, the risks from bubbles and a resurgence of problems remain. Capital flows increased sixfold from 1998 to 1999 , reaching $\$ 39$ billion, and are projected to rise to $\$ 59$ billion in 2000 . See "Flood of Capital seen as Recovery Threat," South China Morning Post, 21 March 2000.

19 "Alcatel office to be launched in Shanghai," Wall Street Journal, 18 January 2000.

20 With accession to the WTO, competition in financial services could increase if China reforms its banking sector and levels the playing field (Harner 2000).

21 Steinfeld "China Survey," Financial Times, 1 October 1999; "Mission Critical," Far Eastern Economic Review, 9 September 1999; and World Bank 1999b.

22 Development of the domestic financial market will be aided by a series of government moves, among which is the raising of the ceilings on stock market investments by insurance companies from 5 to 10 percent. This will increase the volume of liquidity available to finance new share issues ("China to boost liquidity in share market," Financial Times,21 March 2000).

23 It is projected that 2000 firms will be listed by 2010 and market capitalization could reach 13 trillion yuan. "China Equity Development," Oxford Analytica, 17 August 2000.

24 In fact, with two major financial centers already in the region-Tokyo and Hong Kong, there may not be a role for a third center of equivalent scale, especially given the advances in communications favoring a few large nodes linked to many smaller ones in a hierarchical system (Coyle 1997).

25 China devotes 10 percent of GDP to infrastructure and housing development, with housing alone accounting for 6 percent of GDP. This has resulted in an oversupply of housing in the medium and higher price range.

26 Shanghai's Narada Group, a private company, is one of a number of new firms involved in building and operating toll roads in the metropolitan area ("Roads to Riches," Far Eastern Economic Review, 23 September 1999).

27 The airport opened with a 4,000-meter runway and one terminal building, with an annual capacity of handling 20 million passengers and 0.75 million tons of freight. When completed eventually with the planned four runways, the airport will be able to handle 70-80 million passengers and 5 million tons of cargo every year (Shanghai Star, 19 March 1999).

28 Kennedy 2000; "China: Equity Market Development," Oxford Analytica, 17 August 2000.

29 Total fixed asset investment includes investment in capital construction, technical upgrading and transformation, investment by urban and rural collective units, real estate investment, investment by urban and rural residents in private housing construction, and other investment of ownership units (Shanghai Statistical Bureau 1999).

30 See "Water business is hot as more cities decide to tap private sector," Wall Street Journal, 9 November 1998.

31 In the first half of 1999, more than 20,000 families engaged in such trading (Shanghai Star, 30 July 1999). 
32 In 1999, Shanghai terminated the welfare housing system that had been allocating housing to all urban residents at nominal rent levels, in either work units housing or municipal public housing. However, qualified low-income residents can still acquire such housing in the future, and many existing residents are not forced to purchase property/lease rights to their housing.

33 For instance, FDI inflows to Shanghai in 1998 were $\$ 3.64$ billion as against $\$ 2.06$ billion in Beijing and $\$ 2.52$ billion in Tianjin (Shanghai Statistical Bureau 1999).

34 Recently a powerful animation company has been set up, with dreams of becoming China's Disney and subsequent creation of the nation's first higher-learning animation program ("China sets sights on animation," Variety, 3 January 2000).

35 A Software Park is being developed jointly by the Ministry of Information Industry and the city government.

36 By the first quarter of 1999, for instance, grade A office space in Pudong had a vacancy rate reaching 65 percent. Shanghai Star, 28 May 1999.

37 It is not clear whether, in a capitalist system, a functioning land market should be the sole mechanism through which urban land is allocated (see Haila 1999).

38 The city has seen an increase in annual enrollment for universities from 19,000 in 1991-1995 to 30,000 in 1996-2000, for adult continuing education from 10,000 to 18,000 , and for vocational schools from 22,000 to 35,000. See Shanghai Academy of Social Sciences, 1997.

39 Projections by several local research institutions show that, because of the aging population, the volume of resident workforce (age 15-59) will begin to decline after 2005 and by about 2 million in 2030. See Shixun Gui, "Shanghai's Population Trends and Social Security Pensions" (Shanghai: East China Normal University, mimeo, 1999).

40 For instance, the city's 1997 Floating Population Survey reports that close to a half million of migrants have lived in the city for over five years (Zhang and others 1998). So far the city allows migrants to stay for a prolonged period as long as they properly maintain and renew temporary residence permits. Periodically, the Public Security Bureau conducts random checkup and deports those without work and residence permits back to their origin.

41 An important influence will be the significant degree of foreign ownership of assets resulting from FDI. This could approach a third of total assets in five to six years. 


\section{References}

Abu-Lughod. Janet L. 1999. New York, Chicago, Los Angeles: America's Global Cities. Minneapolis-London: University of Minnesota Press.

Bloom, David E. and Jeffrey G. Williamson. 1998. "Demographic Transitions and Economic Miracles in Emerging Asia." Department of Economics, Harvard University: Mimeo.

Castells, Manuel. 1996. The Rise of Network Society. Malden, MA: Blackwell Publishers.

Chiu, Rebecca L. H. 1996. "Housing," in Y. M. Yeung and Sung Yun-wing, eds. Shanghai: Transformation and Modernization under China's Open Policy. Hong Kong: The Chinese University Press.

Chowdhury, Neel. 2000. "Can Citibank Crack the China Market?" Fortune. September 18.

Clarke, Susan E. and Gary L. Gaile. 1998. The Work of Cities. Minneapolis-London: University of Minnesota Press.

Cooper, Richard N. 1999. "Should Capital Controls be Banished?" Brookings Papers on Economic Activity, No. 1, p. 89-141. Washington, DC.

Coyle, Diane. 1997. The Weightless World. Cambridge, MA: MIT Press.

Deane, James. 1999. "China's Great Leap into the Information Society." Development and Cooperation (July/August).

Dowall, David E. 1993. "Establishing Urban Land Markets in the People's Republic of China." Journal of the American Planning Association 59, 2 (Spring): 182-192.

Edwards, Sebastian, 1999. "How Effective are Capital Controls." Journal of Economic Perspectives 13, 4: 65-84.

Easterly, William, Roumeen Islam and Joseph Stiglitz. 1999. "Shaken and Stirred: Explaining Growth and Volatility." World Bank Working Paper, Washington, D.C.

Enright, Michael J., Edith E. Scott and David Dodwell. 1997. The Hong Kong Advantage. Oxford and New York: Oxford University Press.

Frankel, Jeffrey and David Roemer. 1999. "Does Trade Course Growth." American Economic Review 89, 3: 379-98.

Friedmann, John, 1998. "World City Futures: The Role of Urban and Regional Policies in the Asia Pacific Region," in Yue-man Yeung, ed. Urban Development in Asia: Retrospect and Prospect. Hong Kong: Chinese University of Hong Kong Press. 
Friedmann, John. 1995. "Where We Stand: A Decade of World City Research," in Paul L. Knox and Peter J. Taylor, eds. World Cities in a World-System. Cambridge: Cambridge University Press.

Friedman, Thomas. 1999. The Lexus and the Olive Tree. Harper Collins.

Gaubatz, Piper. 1999. "China's Urban Transformation: Patterns and Processes of Morphological Change in Beijing, Shanghai and Guangzhou." Urban Studies 36, 9 (August): 1495-1521.

Goodman, Bryna. 1995. Native Place, City and Nation: Regional Networks and Identities in Shanghai, 1853-1937. Berkeley, CA: University of California Press.

Gordon, Ian. 1999. "Internationalism and Urban Competition." Urban Studies 36, 5-6: 10011027.

Graham, Stephen. 1999. "Global Grids of Glass: On Global Cities, Telecommunications and Planetary Urban Networks." Urban Studies 36, 5-6 (May): 929-949.

Haila, Anne. 1999. "Why is Shanghai Building a Giant Speculative Property Bubble?" International Journal of Urban and Regional Research 23, 3 (September): 583-588.

Harner, Stephen M. 2000. "Financial Services and WTO: Opportunities Knock." The China Business Review (March-April).

Hartford, Kathleen. 2000. "Cyberspace with Chinese Characteristics." Current History (September): 255-262.

Hayes, Declan. 2000. Japan's Big Bang. Boston: Tuttle.

Howe, Christopher (ed.). 1981. Shanghai: Revolution and Development in an Asian Metropolis. Cambridge: Cambridge University Press.

Jiang, Dianchun, Jean Jinghan Chen and David Isaac. 1998. "The Effect of Foreign Investment on the Real Estate Industry in China." Urban Studies 35, 11 (November): 2101-2110.

Johnson, Linda Cooke. 1995. Shanghai: From Market Town to Treaty Port, 1074-1858. Stanford, CA: Stanford University Press.

Kennedy, Gabriela. 2000. "E-commerce: The Taming of the Internet in China." The China Business Review (July-August).

Kray, Aart. 1998. "In Search of the Macroeconomic Effects of Capital Account Liberalization" World Bank Working Paper, Washington, D.C. 
Landes, David S. 1998. The Wealth and Poverty of Nations. New York and London: W.W. Norton and Company.

Levine, Ross. 1997. "Financial Development and Economic Growth: Views and Agenda." Journal of Economic Literature 35, 4: 688-726.

Li, Shantong and Fan Zhai. 2000. "Prospects of Chinas' Economic Development in the Next 20 Years." Mimeo, Beijing: Development Research Center.

Lu, Hanchao. 1999. Beyond the Neon Lights: Everyday Shanghai in the Early Twentieth Century. Berkeley, CA: The University of California Press.

Martin, Will, B. Dimaranan and T.W. Hertel. 1999. "Trade Policy Structural Change and China's Trade Growth." Mimeo, World Bank, Washington, D.C.

Meyer, David R. 2000. Hong Kong as a Global Metropolis. Cambridge: Cambridge University Press.

Murphy, Rhodes. 1953. Shanghai: Key to Modern China. Cambridge, MA: Harvard University Press.

Newfarmer, Richard and Dana M. Liu. 1998. "China's Race with Globalization." The China Business Review (July-August): 8-13.

Ochi, Hiroo. 1997. "The Environment for Locating Business Operatives in Major East Asian Cities." Tokyo: Japan Development Bank Research Report, No. 65.

Olds, Kris. 1997. "Globalizing Shanghai: The 'Global Intelligence Corps' and the Building of Pudong." Cities: The International Journal for Urban Policy and Planning 14, 2 (April): 109-123.

Pearson, Margaret M. 2000. "China's Track Record in the Global Economy." The China Business Review (January-February): 48-51.

Pott, Francis Lister Hawks. 1928. A Short History of Shanghai. Shanghai: Kelly and Walsh, Ltd.

Rawski, Thomas G. 1999/2000. “China's Economy after Fifty Years.” International Journal 55, 1 (Winter): 62-79.

Sachs, Jeffrey D. and Andrew Warner. 1997. "Fundamental Sources of Long-Run Growth." American Economic Review 87, 2: 184- 88.

Sachs, Jeffrey D. and Andrew Warner. 1995. "Economic Reform and the Process of Global Integration." Brookings Papers on Economic Activity. Washington, DC. 
Sassen, Saskia. 1991. The Global City: New York, London, Tokyo. Princeton, NJ: Princeton University Press.

Segal, Gerald. 1999. "Does China Matter?” Foreign Affairs 78, 5 (September/October).

Shanghai Academy of Social Sciences. 1997. Shanghai Entering the New Century: Issues in Social Development. Shanghai: Shanghai Academy of Social Sciences Press.

Shanghai Construction Commission. 1997. Shanghai Urban Construction: Achievements in the Eighth Five-Year Plan Period and Long-Term Plans. Beijing: China Statistical Publishing House.

Shanghai Statistical Bureau. 1996-1999. Statistical Yearbook of Shanghai. Beijing: China Statistical Publishing House.

1997. Shanghai Investment and Construction Statistical Yearbook, 1997. Shanghai: Shanghai News Press (Shanghai Xinwen Chubanju).

Shi, Peijun, Lin Hui and Liang Jinshe. 1996. "Shanghai as a Regional Hub," in Y. M. Yeung and Sung Yun-wing, eds. Shanghai: Transformation and Modernization under China's Open Policy. Hong Kong: The Chinese University Press.

Steinfeld, Edward S. 1999. "Beyond the Transition: China's Economy at Century's End." Current History 98 (September): 629.

Wang, Yukun. 1998. "Urban Development Towards the Year 2000," in Yue-man Yeung, ed. Urban Development in Asia: Retrospect and Prospect. Hong Kong: Chinese University of Hong Kong Press.

Wei, Betty Peh-T'i. 1987. Shanghai: Crucible of Modern China. Oxford and New York: Oxford University Press.

World Bank. 1997. Sharing Rising Incomes: Disparities in China. Washington, DC: The World Bank.

World Bank. 1999a. World Development Report 1999/2000: Entering the $21^{\text {st }}$ Century. New York: Oxford University Press, for the World Bank.

World Bank. 1999b. "China." Washington DC: The World Bank, September, Mimeo.

Wu, Friedrich and Jill Wong. 1997. "China's Financial Powerhouse." China Business Review, March-April.

Wu, Fulong. 2000. "The Global and Local Dimensions of Place-Making: Remaking Shanghai as a World City." Urban Studies 37, 8: 1359-1377. 
Wu, Weiping. 1999a. "City Profile: Shanghai." Cities: The International Journal for Urban Policy and Planning 16, 3 (May): 207-216.

. 1999b. "Reforming China's Institutional Environment for Urban Infrastructure Provision." Urban Studies 36, 13 (December): 2263-2282.

Yeung, Yue-man. 1996. "Introduction," in Y. M. Yeung and Sung Yun-wing, eds. Shanghai: Transformation and Modernization under China's Open Policy. Hong Kong: The Chinese University Press.

Yeung, Yue-man and Xiaojian Li. 1999. "Bargaining with Transnational Corporations: The Case of Shanghai." International Journal of Urban and Regional Research 23, 3: 513-533.

Yu, Qiao 1998. "Capital Investment, International Trade and Economic Growth in China: Evidence in the 1980s-1990s." China Economic Review 9, 1: 73-84.

Yu, Yongding. 2000. "Globalization from China's Perspectives." Mimeo, Beijing: Chinese Academy of Social Sciences, Institute of World Economics and Politics.

Yusuf, Shahid and Weiping Wu. 1997. The Dynamics of Urban Growth in Three Chinese Cities. New York: Oxford University Press for the World Bank.

Zhang, Shenghua and others (eds.). 1998. The Current Status and Future of Shanghai's Floating Population. Shanghai: Shanghai: East China Normal University Press.

Zhao, Mao. 1999. "Reform Experience and Future Development of Shanghai's Retirement Insurance Fund." Shanghai Labor and Social Protection Bureau: Mimeo. 
Table 1. Indices of Gross Domestic Product in Shanghai (1952=100)

\begin{tabular}{rcccccccc}
\hline Year & GDP & $\begin{array}{c}\text { Primary } \\
\text { sector }\end{array}$ & $\begin{array}{c}\text { Secondary } \\
\text { sector }\end{array}$ & $\begin{array}{c}\text { Tertiary } \\
\text { sector }\end{array}$ & $\begin{array}{c}\text { Transport \& } \\
\text { communications }\end{array}$ & $\begin{array}{c}\text { Wholesale, retail } \\
\text { \& food services }\end{array}$ & $\begin{array}{c}\text { Banking \& } \\
\text { insurance }\end{array}$ & $\begin{array}{c}\text { Real } \\
\text { estate }\end{array}$ \\
\hline 1985 & $1,596.6$ & 244.2 & $2,602.9$ & 715.0 & $1,833.1$ & 391.3 & $3,076.7$ & $1,154.0$ \\
1986 & $1,666.9$ & 243.8 & $2,707.0$ & 757.9 & $1,906.4$ & 394.0 & $3,544.4$ & $1,065.1$ \\
1987 & $1,791.9$ & 237.2 & $2,907.3$ & 825.4 & $1,973.1$ & 397.9 & $4,274.5$ & $1,175.9$ \\
1988 & $1,972.9$ & 248.2 & $3,180.6$ & 929.4 & $2,085.6$ & 461.2 & $5,185.0$ & $1,198.2$ \\
1989 & $2,032.1$ & 248.9 & $3,231.5$ & 995.4 & $2,164.9$ & 465.8 & $6,548.7$ & $1,286.9$ \\
1990 & $2,103.2$ & 259.6 & $3,322.0$ & $1,048.2$ & $2,437.7$ & 476.2 & $6,961.3$ & $1,020.5$ \\
1991 & $2,252.5$ & 260.6 & $3,547.9$ & $1,137.3$ & $2,627.8$ & 547.0 & $7,135.3$ & $1,575.7$ \\
1992 & $2,585.9$ & 261.6 & $4,158.1$ & $1,273.8$ & $2,869.6$ & 643.9 & $7,784.6$ & $1,905.0$ \\
1993 & $2,971.2$ & 254.5 & $4,852.5$ & $1,441.9$ & $3,079.1$ & 727.0 & $9,193.6$ & $2,133.6$ \\
1994 & $3,396.1$ & 261.9 & $5,541.6$ & $1,669.7$ & $3,300.8$ & 803.3 & $11,924.1$ & $2,656.3$ \\
1995 & $3,875.0$ & 278.7 & $6,361.8$ & $1,888.4$ & $3,565.4$ & 921.4 & $12,568.0$ & $7,190.6$ \\
1996 & $4,378.8$ & 292.6 & $7,067.9$ & $2,224.5$ & $4,007.5$ & $1,029.2$ & $16,313.3$ & $8,923.5$ \\
1997 & $4,934.9$ & 304.9 & $7,817.1$ & $2,618.2$ & $4,344.1$ & $1,227.8$ & $20,587.4$ & $10,288.8$ \\
1998 & $5,433.3$ & 311.6 & $8,458.1$ & $2,992.6$ & $4,717.7$ & $1,355.5$ & $23,016.7$ & $12,696.4$ \\
\hline
\end{tabular}

Source: Shanghai Statistical Bureau, 1999. 
Table 2. Improvements in Shanghai's Infrastructure Services, 1991 and 1998

\begin{tabular}{lrr}
\hline & 1991 & 1998 \\
\hline Per capita paved road (square meters) & 2.3 & 5.0 \\
Per capita open space (square meters) & 1.1 & 3.0 \\
Per capita living space (square meters) & 6.7 & 9.7 \\
Capacity for treating wastewater (million tons/day) & 0.4 & 1.9 \\
Access to gas (percent) & 62.0 & $91.5^{*}$ \\
Per capita annual domestic water consumption (tons) & 71.2 & $104.6^{*}$ \\
Wastewater treated (percent) & 7.6 & $30.2^{*}$ \\
\hline
\end{tabular}

* 1996 figures.

Source: Shanghai Statistical Bureau, 1997 and 1999; Shanghai Construction Commission, 1997.

Table 3 Investment in Shanghai's Urban Infrastructure (billions of yuan), 1981-98

$\begin{array}{llllllllll}1981 & 1986 & 1991 & 1992 & 1993 & 1994 & 1995 & 1996 & 1997 & 1998\end{array}$

\begin{tabular}{lrrrrrrrrrr}
\hline & & & & & & & & & & \\
Electric power & 0.35 & 0.57 & 1.98 & 1.97 & 2.58 & 4.16 & 5.73 & 7.76 & 8.02 & 8.96 \\
Transportation & 0.24 & 0.66 & 1.45 & 1.50 & 3.18 & 3.68 & 2.59 & 6.97 & 8.51 & 10.88 \\
Postal \& telecommications & 0.04 & 0.18 & 0.46 & 0.64 & 1.47 & 3.59 & 5.34 & 7.76 & 6.10 & 7.27 \\
Public utilities & 0.06 & 0.57 & 0.92 & 1.26 & 3.79 & 2.68 & 3.50 & 4.83 & 5.22 & 5.84 \\
Municipal works & 0.09 & 0.50 & 1.34 & 3.06 & 5.78 & 9.71 & 10.21 & 10.57 & 13.43 & 20.20 \\
& & & & & & & & & & \\
Total & 0.78 & 2.48 & 6.14 & 8.43 & 16.79 & 23.82 & 27.38 & 37.88 & 41.29 & 53.14 \\
As percentage of TIFA & 14.4 & 16.9 & 23.8 & 23.6 & 25.7 & 21.2 & 17.1 & 19.4 & 20.9 & 27.0 \\
& & & & & & & & & & \\
\hline
\end{tabular}

Note: TIFA, total investment in fixed assets. Public utilities include water supply and drainage, residential gas and heating supply, and public transportation. Municipal works include city streets, bridges, tunnels, sewerage, parks, sanitation and waste management, and flood control.

Source: Shanghai Statistical Bureau, 1999. 
Table 4. Utilized Foreign Investment in Shanghai, 1995-1998 (USSmillion)

\begin{tabular}{|c|c|c|c|c|c|c|c|c|}
\hline \multirow[b]{3}{*}{ Foreign direct investment [1] } & \multicolumn{2}{|c|}{1995} & \multicolumn{2}{|c|}{1996} & \multicolumn{2}{|c|}{1997} & \multicolumn{2}{|c|}{1998} \\
\hline & Amount & Percent & Amount & $\overline{\text { Percent }}$ & Amount & Percent & Amount & ercent \\
\hline & 3250.0 & 100.0 & 4715.8 & 100.0 & 4808.0 & 100.0 & 3637.9 & 100.0 \\
\hline Joint ventures & 1753.9 & 54.0 & 2561.7 & 54.3 & 2095.0 & 43.6 & 1486.4 & 40.9 \\
\hline Cooperative operation & 1088.0 & 33.5 & 1179.0 & 25.0 & 784.0 & 16.3 & 480.6 & 13.2 \\
\hline Wholly foreign-owned & 363.4 & 11.2 & 721.3 & 15.3 & 1920.0 & 39.9 & 1274.0 & 35.0 \\
\hline Primary sector & 2.6 & 0.1 & 3.2 & 0.1 & 1.0 & 0.0 & 4.0 & 0.1 \\
\hline Secondary sector & 1475.9 & 45.4 & 2520.0 & 53.4 & 2707.5 & 56.3 & 2297.6 & 63.2 \\
\hline Tertiary sector & 1771.5 & 54.5 & 2192.6 & 46.5 & 2099.8 & 43.7 & 1336.3 & 36.7 \\
\hline Manufacturing & 1450.6 & 44.6 & 2458.4 & 52.1 & 2695.3 & 56.1 & 2270.7 & 62.4 \\
\hline Real estate & 681.8 & 21.0 & 1052.9 & 22.3 & 1325.9 & 27.6 & 923.4 & 25.4 \\
\hline Social services & 489.9 & 15.1 & 281.0 & 6.0 & 225.9 & 4.7 & 224.2 & 6.2 \\
\hline Wholesale, retail and food services & 539.4 & 16.6 & 570.5 & 12.1 & 222.8 & 4.6 & 52.0 & 1.4 \\
\hline Transport and communications & 25.6 & 0.8 & 8.5 & 0.2 & 16.8 & 0.3 & 18.6 & 0.5 \\
\hline Hong Kong & 1894.0 & 58.3 & 2232.0 & 47.3 & 1756.1 & 36.5 & 1026.1 & 28.2 \\
\hline United States & 364.0 & 11.2 & 687.6 & 14.6 & 855.7 & 17.8 & 864.8 & 23.8 \\
\hline Japan & 237.6 & 7.3 & 625.9 & 13.3 & 461.1 & 9.6 & 374.4 & 10.3 \\
\hline United Kingdom & 108.6 & 3.3 & 204.7 & 4.3 & 155.8 & 3.2 & 132.8 & 3.7 \\
\hline Taiwan & 177.5 & 5.5 & 327.5 & 6.9 & 161.7 & 3.4 & 127.6 & 3.5 \\
\hline Singapore & 78.0 & 2.4 & 153.7 & 3.3 & 372.9 & 7.8 & 116.0 & 3.2 \\
\hline Foreign loans [2] & 2033.2 & & 2789.0 & & 1537.0 & & 1178.0 & \\
\hline Other foreign investment [3] & 15.0 & & 5.1 & & 0.0 & & 0.0 & \\
\hline All foreign investment $[1]+[2]+[3]$ & 5298.1 & & 7510.0 & & 6345.0 & & 4816.0 & \\
\hline Projects with technical import & 674.5 & & 1015.7 & & 695.5 & & 1332.9 & \\
\hline
\end{tabular}

Sources: Shanghai Statistical Bureau, 1996-1999. 


\section{Policy Research Working Paper Series}

Title

WPS2602 Sugar Policy and Reform

WPS2603 How the Quality of Institutions Affects Technological Deepening in Developing Countries

WPS2604 Eliminating Excessive Tariffs on Exports of Least Developed Countries

WPS2605 The Macroeconomic Impact of Bank Bank Capital Requirements in Emerging Economies: Past Evidence to Assess the Future

WPS2606 Exchange Rate Risk Management: Evidence from East Asia

WPS2607 The Economical Control of Infectious Disease

WPS2608 Financial Development and International Trade: Is There a Link?

WPS2609 Financial Dependence and International Trade

WPS2610 Crisis and Contagion in East Asia: Nine Lessons

WPS2611 Trade and Production Fragmentation: Central European Economies in European Union Networks of Production and Marketing

WPS2612 Contractual Savings, Capital Markets, and Firms' Financing Choices

WPS2613 Foreign Direct Investment and Poverty Reduction

WPS2614 South-South Regional Integration and Industrial Growth: The Case of the Andean Pact
Author

Date

Donald F. Larson

Brent Borrell

George R. G. Clarke

May 2001

Bernard Hoekman

Francis $\mathrm{Ng}$

Marcelo Olarreaga

Maria Concetta Chiuri

Giovanni Ferri

Giovanni Majnoni

George Allayannis

Gregory W. Brown

Leora F. Klapper

Mark Gersovitz

Jeffrey S. Hammer

Thorsten Beck

Thorsten Beck

Masahiro Kawai Richard Newfarmer Sergio Schmukler

Bartlojiej Kaminski

Francis $\mathrm{Ng}$

June 2001

June 2001

Gregorio Impavido Alberto R. Musalem Thierry Tressle

Michael Klein

Carl Aaron

Bita Hadjimichael

Dorsati H. Madani

May 2001

May 2001

May 2001

May 2001

May 2001

June 2001

June 200

June 2001
Contact for paper

P. Kokila 33716

P. Sintim-Aboagye 38526

L. Tabada 36896

E. Mekhova 85984

A. Yaptenco 31823

H. Sladovich 37698

L. Tabada 36896

P. Braxton 32720

Z. Fanai 33605

R. Simms 37156

A. Yaptenco 38526

A. Yaptenco 38526

E. Khine 37471

720




\section{Policy Research Working Paper Series}

Title

WPS2615 Trade, Growth, and Poverty

WPS2616 Reforming Land and Real Estate Markets
Author

David Dollar

Aart Kraay

Ahmed Galal

Omar Razzaz
Contact

Date

June 2001

E. Khine

37471

June 2001

D. Dietrich

34995 